EUROPEAN CENTRAL BANK

WORKING PAPER SERIES

NO. 320 / MARCH 2004

\title{
INSTITUTIONS
}

\section{AND SERVICE \\ EMPLOYMENT: \\ A PANEL STUDY \\ FOR OECD \\ COUNTRIES}

by Julián Messina

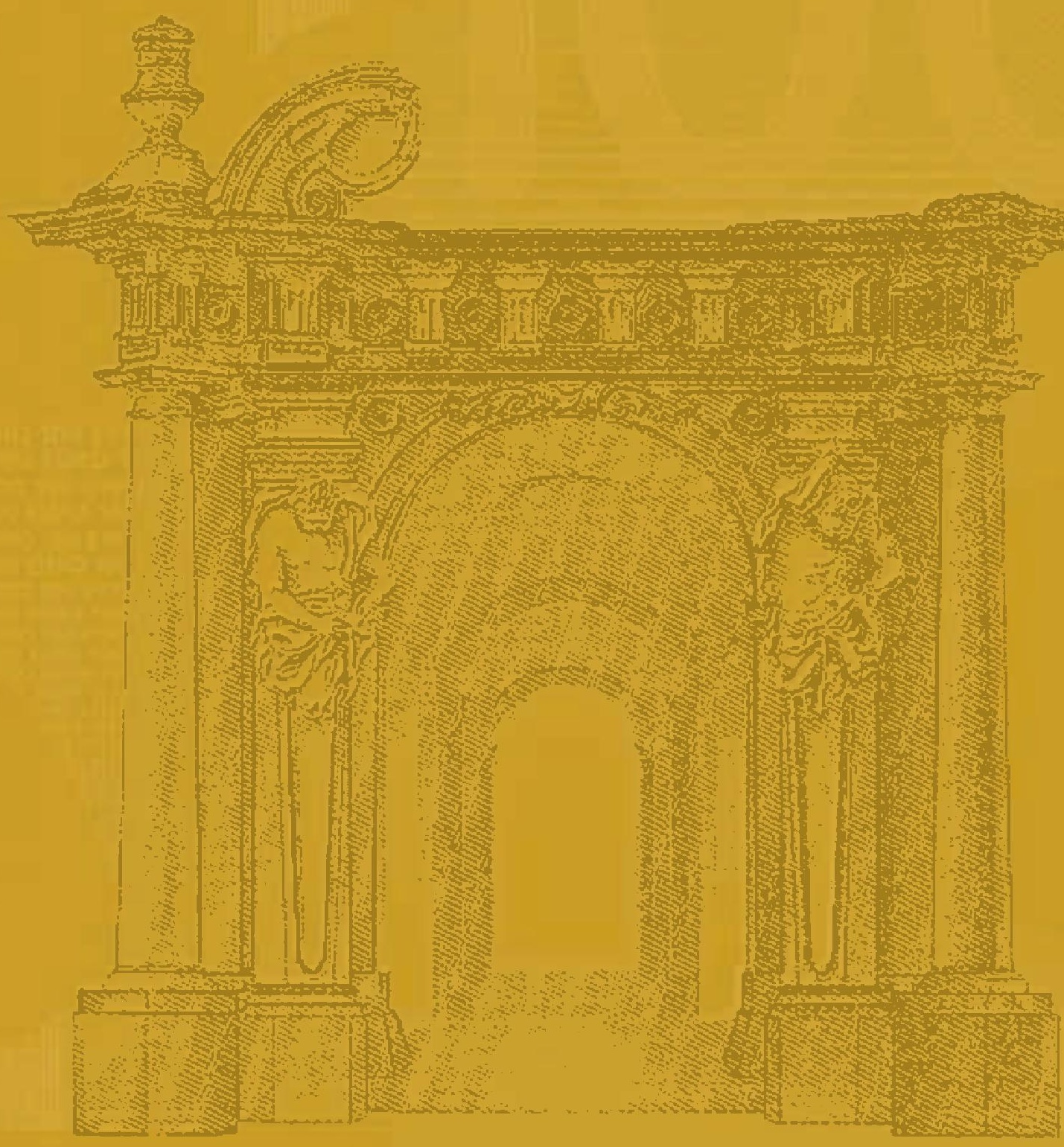




\section{INSTITUTIONS AND SERVICE EMPLOYMENT: A PANEL STUDY FOR OECD COUNTRIES'}

by Julián Messina ${ }^{2}$

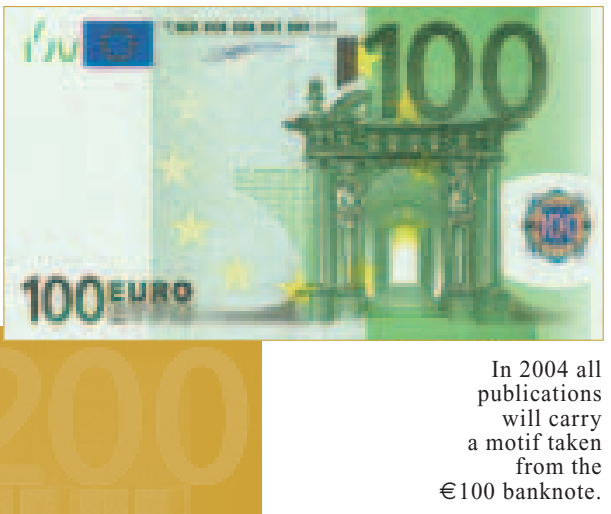

This paper can be downloaded without charge from http://www.ecb.int or from the Social Science Research Network electronic library at http://ssrn.com/abstract_id $=526983$.

\footnotetext{
I I am particularly indebted to Giuseppe Bertola for lengthy discussions and guidance. Andrea Ichino, Juan Francisco Jimeno, Giuseppe Nicoletti, Roberto Perotti and Anna Sanz de Galdeano provided helpful comments on an previous version of this paper, and therefore are gratefully acknowledged. This paper also benefited from comments by an anonymous referee and seminar participants at the ECB and the European University Institute MacroWorkshop. All errors are mine. This paper reflects the views of the author, and not necessarily those of the European Central Bank. 


\section{드 European Central Bank, 2004}

\section{Address}

Kaiserstrasse 29

60311 Frankfurt am Main, Germany

Postal address

Postfach 160319

60066 Frankfurt am Main, Germany

Telephone

+496913440

\section{Internet}

http://www.ecb.int

Fax

+496913446000

Telex

411144 ecb d

All rights reserved.

Reproduction for educational and noncommercial purposes is permitted provided that the source is acknowledged.

The views expressed in this paper do not necessarily reflect those of the European Central Bank.

The statement of purpose for the ECB Working Paper Series is available from the ECB website, http://www.ecb.int.

ISSN 1561-0810 (print)

ISSN 1725-2806 (online) 


\section{CONTENTS}

Abstract 4

Non-technical summary 5

1 Introduction 7

2 The determinants of service employment 8

2.1 Income per capital and sectoral structure 8

2.2 Service employment: the sources of cross-country differences $\quad 10$

2.2.1 Trade specialization 10

2.2.2 Labor market institutions I0

2.2.3 Product market regulations ||

2.2.4 Exogenous shifts of internal demand

3 Methodology and the data $\quad$ I2

3.1 Empirical methodology $\quad 12$

3.2 The data 13

4 Empirical results I4

5 Conclusions 20

References 2I

Appendix 24

Tables and figures 26

European Central Bank

working paper series 


\begin{abstract}
We live in a service economy, but the extent of development of service employment differs across developed countries. This paper assesses the role of structural factors and institutions in explaining the common patterns and main differences in the recent expansion of service employment in OECD countries. It finds that GDP per capita, the size of the government sector and the extent of urbanization are positively associated with the service employment share. However, the evidence suggests that laws and institutions such as product market regulations, unions and more coordinated wage-setting systems are hampering the expansion of service employment.
\end{abstract}

Keywords: Service Industries, Product and Labor Market Regulations, Employment, Structural Change

JEL Classification: J21, L80, L51. 


\section{Non-technical summary}

During the last century, service industries have absorbed a continuously increasing share of the labour force in the OECD countries, while agricultural activities have lost weight dramatically. Thus, the growth of the service employment share stands out as a prominent regularity of the growth process of modern economies. However, there are still remarkable differences in the relative sizes of the service employment share across countries with similar income per capita. For instance, Italy and Germany had service employment shares barely exceeding 60 per cent in the second half of the 1990s, more than 10 percentage points lower than in the US, Australia or Canada. In the light of these differences, it is not surprising then that the lack of dynamism in the service sector in Europe is often blamed as one of the key elements in explaining the poor employment performance of the 1980s and 1990s.

The aim of this paper is twofold. First, it extends previous literature on the determinants of service employment across developed economies. A special emphasis is placed on the sources of cross-country variation in the size of the service sector within this relatively homogeneous group of countries. Second, it assesses the role of product and labour market institutions in determining the sectoral structure of modern economies. While the role of institutions in the determination of labour market aggregates such as employment or unemployment has been extensively studied, their effects on the sectoral structure of the economy have been largely ignored in the literature. Gordon (1997) suggests that minimum wages and wage compression possibly induced by unions in Europe is cutting back jobs in the lower tail of the skill distribution within the service sector. On the product market side of the institutional spectrum, Messina (2003) shows that economy-wide product market regulations which restrain entry and mobility at the firm level have asymmetric effects on the sectoral structure of the economy, hindering the "natural" pattern of sectoral reallocation of labour, and thus obstructing the development of the service sector. This paper assesses the empirical relevance of these two hypotheses.

The analysis, based on a panel of 27 OECD countries observed within the 1970-1998 period, confirms the importance of structural factors in the determination of service employment. Across most specifications, it is found that GDP per capita, the productivity gap of services with respect to manufacturing, the size of the public sector and the degree of urbanization have a positive and statistically significant effect on the service employment share. On the contrary, the results stress important institutional constraints to the development of service employment. Stringent barriers to the creation of new firms due to administrative burdens to business startups and more unionized and coordinated wage-setting structures within a country are associated with a lower service employment share. Regarding product market regulations, this result is in line with theoretical in- 
sights that suggest that product market regulations hinder the development of sectors whose demand is income elastic, such as Financial and Business Services or Social and Personal Services. This is partially supported in an empirical analysis of the determinants of four service branches. The disaggregated analysis also uncovers that the main negative effects of unions and coordinated wage-setting structures falls on Retail and Wholesale Trade. Taking into account that this sector is intensive in low skill labour, this can be read as supportive evidence that more unionized labour markets where bargaining takes place at a very centralized or co-ordinated level are cutting back low skilled jobs. 


\section{Introduction}

During the last century, service industries have absorbed a continuously increasing share of the labour force in the OECD countries, while agricultural activities have lost weight dramatically. Thus, the growth of the service employment share stands out as a prominent regularity of the growth process of modern economies. However, there are still remarkable differences in the relative sizes of the service employment share across countries with similar income per capita. For instance, Italy and Germany had service employment shares barely exceeding 60 per cent in the second half of the 1990s, more than 10 percentage points lower than in the US, Australia or Canada. In the light of these differences, it is not surprising then that the lack of dynamism in the service sector in Europe is often blamed as one of the key elements in explaining the poor employment performance of the 1980s and 1990s. ${ }^{1}$

Most empirical and theoretical studies have concentrated on documenting the crosscountry regularities in the process of structural change. These empirical analyses date back to the pioneering studies of Clark (1957) and Kuznets (1966), who described the main features of the process of sectoral reallocation of resources that accompanies the growth of modern economies. A key feature of the subsequent literature has been to disentangle wether the forces behind the growth of service employment are related to demand factors as proposed by Clark (1957), or to the slow growth of service productivity as suggested by Baumol (1967). ${ }^{2}$ However, there is little emphasis on this literature regarding potential sources of cross-country divergence in the sectoral allocation of resources.

A vast empirical literature analyzes the effects of institutions on unemployment, relating the experience observed in different countries to the role of labour market policies (Scarpetta, 1996 and Nickell, 1997), their interaction with macroeconomic shocks (Blanchard and Wolfers, 2000) and demographic factors (Bertola et al., 2002; Jimeno and Rodriguez-Palenzuela, 2002). Similarly, a growing literature relates institutional factors to the employment rates observed across OECD countries (e.g. Nicoletti et al. 2000 and Nickell and Nunziata, 2001).

The aim of this paper is twofold. First, it extends previous literature on the determinants of service employment across developed economies. A special emphasis is placed on the sources of cross-country variation in the size of the service sector within this relatively homogeneous group of countries. Second, it assesses the role of product and

\footnotetext{
${ }^{1}$ For instance, Mr. A. Larsson, Director General of the Employment and Social Affairs of the European Commission stated during a speech at the LSE that "The real difference between Europe and the US is employment in the services sector. The fact is that, if Europe had had the same employment in the service sector as the US, there would be more than 30 million additional jobs in Europe." The document can be found at: http://europa.eu.int/comm/dg05/index_en.htm

${ }^{2}$ Fuchs (1968) examines the issue in detail. For a recent review of the facts see OECD (2000).
} 
labour market institutions in determining the sectoral structure of modern economies. Regarding the latter, Gordon (1997) suggests that minimum wages and wage compression possibly induced by unions in Europe is cutting back jobs in the lower tail of the skill distribution within the service sector. On the product market side of the institutional spectrum, Messina (2003) shows within a fairly standard general equilibrium model that economy-wide product market regulations which restrain entry and mobility at the firm level have asymmetric effects on the sectoral structure of the economy, hindering the "natural" pattern of sectoral reallocation of labour, and thus obstructing the development of the service sector. Although there is no evidence at the aggregate level of this hypothesis, findings in Bertrand and Kramarz (2002) are in line with this hypothesis, suggesting that more stringent zoning laws have hindered job creation in the retail sector in France.

The analysis, based on a panel of 27 OECD countries observed within the 1970-1998 period, confirms the importance of structural factors in the determination of service employment. It is found that GDP per capita, the productivity gap of services with respect to manufacturing, the size of the public sector and the degree of urbanization have a positive and statistically significant effect on the service employment share. On the contrary, the results stress important institutional constraints to the development of service employment. Countries where the legislation affecting product markets is more stringent present a share of the workforce employed in service activities relatively low when compared with similar but less regulated economies. The results are also consistent with the view that the service sector is less dynamic in more unionized economies where the wage-setting system is more coordinated. Distinguishing the analysis across four service branches, it is found that unions play a stronger role in sectors intensive in low skilled labour such as Wholesale and Retail trade, suggesting wage compression as a channel through which unions might hamper the development of the service sector.

The rest of the paper is organized as follows. The next section introduces the main factors that have been mentioned in the literature as determinants of the service employment share. Section 3 describes the empirical methodology and principal characteristics of the data used, while Section 4 presents the main findings of the empirical analysis. Section 5 concludes.

\section{The Determinants of Service Employment}

\subsection{Income per Capita and Sectoral Structure}

The first aspect commonly mentioned in the literature as an engine of structural change is associated with tastes. Clark (1957) argued that once a certain level of development is achieved, modern societies would demand service activities more than proportionally as 
their income continued growing. Therefore, if the income elasticity of services demand is larger than one, the consumption and employment shares of services will increase with the rise of living standards. The second aspect, first put forward in Baumol (1967), highlights supply side forces. In Baumol's view, the main reason for explaining the growth of service employment is the service productivity gap with respect to the manufacturing sector. Baumol observed that measured productivity growth is actually much lower in service industries than in manufacturing and therefore even if the real demand of services is not growing, an increasing amount of resources is required for production in this sector. This will be the case as long as service demand is sufficiently price inelastic, since the counterpart of service productivity growth lagging behind manufacturing productivity would be a constant increase of service relative prices.

Both type of forces predict a positive association between income per capita and the service employment share. However, they offer little guidance with respect to the possible sources of divergence in the service employment share across countries with similar income per capita. In principle, there are no reasons to think that the preference structure of the population in countries at similar stages of development should differ, unless differences in the distribution of income alter substantially the composition of final demand across countries. Similarly, technology flows rapidly across national borders, such that countries with similar income per capita should have a similar technology. Therefore, if tastes or differentials in productivity growth are the main engines of structural change, countries with similar income per capita should have a similar share of the labour force engaged in the production of services.

Figure 1 correlates income per capita and the service employment share observed every decade during the 20 th and late 19 th century for 14 OECD. The similarities in the growth of service employment stand out from the figure, illustrating the common features in the process of structural change. However, a closer look at the relationship between income per capita and the service employment share also uncovers important disparities across countries. Figure 2 shows the snapshot distribution of the service employment share and GDP per capita across a larger sample of OECD countries in the $90 \mathrm{~s}$. While the positive association between both variables is still evident, the graph also shows remarkable differences across economies lying in similar income per capita ranges. Take the Netherlands and Italy, for example. While the former employs $73 \%$ of its labour force in service activities, in the latter the service employment share does not exceed $60 \%$. Something similar could be said about the relative underdevelopment of the service sector in other countries in continental Europe, such as Germany or Austria, when compared to Australia or Canada.

A final aspect commonly mentioned in the literature as an engine of service employment growth is outsourcing. In support of this hypothesis, empirical evidence suggests 
that the employment share in intermediate market services has increased importantly in the major OECD economies during the last decades. ${ }^{3}$ Some authors have proposed that a lesser use of outsourcing by European firms might be behind the difference in the service employment shares when compared to the US. However, this hypothesis has found little empirical support when comparing German and US employment structures (Freeman and Schettkat, 1999). Moreover, differences in firm's outsourcing decisions across countries should be considered endogenous, their sources possibly lying on institutional aspects (which might affect transaction costs for instance) which will be reviewed below.

\subsection{Service Employment: the Sources of Cross-Country Differences}

\subsubsection{Trade specialization.}

Resource endowments shape the patterns of international trade according to the HeckscherOhlin theory. Countries relatively abundant in natural resources will then tend to specialize in the exports of agricultural and raw material goods, importing manufacturing products and drawing resources from the manufacturing sector towards the primary goods sector. However, as more resources are devoted to the production of primary goods, the rise in the real exchange rate induced by the new pattern of trade might trigger an expansion of the non-tradable sector (i.e. service sector). Thus, through the so-called "Dutch disease" phenomenon, countries with a larger endowment of natural resources are expected to have an above average share of employment engaged in service production.

Human capital is another resource that might well be a source of comparative advantage. The service sector is characterized by a relatively skill intensive production when compared to the manufacturing sector, even if some service branches such as restaurants and hotels are intensive in low skill labour. In 1998, the ratio of university to nonuniversity workers engaged in service industries was 0.24 , almost three times larger than in the manufacturing sector (OECD, 2000). If the average level of skills demanded is higher in services, human capital accumulation should be accompanied by an expansion of service exports -and consequently service employment- through the Rybzyinski effect, together with a contraction in the production of manufacturing. ${ }^{4}$

\subsubsection{Labor market institutions.}

Gordon (1997) suggests that several service industries intensive in low skill labour might be relatively underdeveloped in continental Europe where the wage distribution is rela-

\footnotetext{
${ }^{3}$ See Diaz Fuentes (1999) and the references therein.

${ }^{4} \mathrm{~A}$ related literature, beyond the scope of this paper, is concerned with the effects of trade with developing countries on the recent trend of deindustrialization observed in the developed economies. See Saeger (1997) and Rowthorn and Ramaswamy (1999).
} 
tively compressed due to unionized labour and the existence of binding minimum wage laws. A similar argument is raised by Piketty (1998). Indeed, as Gordon points out, the casual European observer that travels to the other side of the Atlantic is surprised by the quantity of service occupations (from shoe-shiners to the number of bar tenders in a restaurant) that he observes there, which seem to be missing in most European countries. A similar negative role in the development of the service sector might be played by unemployment benefits if these institutions effectively compress the wage structure by raising reservation wages. Finally, institutions that hinder the reallocation of employment such as Employment Protection Legislation might, at least temporarily, obstruct the expansion of dynamic service sectors.

\subsubsection{Product Market Regulations}

With regards to product market institutions, Messina (2003) shows that barriers to entry raised by economy-wide product market regulations obstruct the natural pattern of structural change, reducing the service employment share. This general equilibrium effect might be reinforced to the extent that some of these regulations are concentrated on service sub-sectors (e.g. zoning laws or shop opening hours affecting the distribution sector).

\subsubsection{Exogenous shifts of internal demand.}

Some authors stress the importance of exogenous demand shifts in explaining crosscountry differences in the development of service industries. OECD (2000) highlights the importance of the secular incorporation of female workers into the labour force as a possible source of service employment growth. ${ }^{5}$ Thus, cultural differences affecting female labour market participation could be behind the differences in the development of the service sector. Similarly, some aspects in the process of tertiarization like the expansion of leisure services are typical of urban cultures, and therefore closely associated with the process of urbanization. The degree of investment might also affect the sectoral allocation of labour across countries, if investment is intensive in manufacturing goods as suggested by Rowthorn and Ramaswamy (1999). Finally, governments are not only consumers but also important suppliers of services. If private and public services were perfectly substitutable, the sectoral allocation of resources might be unaffected by differences across countries in the size of the public sector. However, there are some services such as defense, justice, public administration and to some extent health care where this substitutability is clearly limited. Moreover, inefficiencies in the public sector might be

\footnotetext{
${ }^{5}$ However, there is an important risk of reverse causality in this case. It might well be the case that the increasing dynamism of service industries in developed economies encouraged the incorporation of women to the labor force.
} 
translated in a larger service employment share even in those sectors where public and private provision are closely substitutes. Thus, a positive effect of the size of the public sector in the determination of the service employment share is expected.

\section{Methodology and the Data}

\subsection{Empirical Methodology}

Let $l_{j t}$ be the labour engaged in service activities as a share of total employment in period $t$ and country $j$. A reduced-form equation explaining the service employment share is specified as follows:

$$
l_{j t}=\alpha+X_{j t} \beta+r_{j} \gamma+\varepsilon_{j t} \quad \text { for } j=1,2 \ldots n \text { and } t=1,2 \ldots T_{j}
$$

where $\alpha$ is a constant and $\varepsilon_{j t}$ is the error term. $X_{j t}$ are a set of time-varying control variables and $r_{j}$ is a time-invariant institutional indicator.

The first set of estimates presented below controls for country specific unobservable heterogeneity. Random effect estimators exploit both the between and within country variation in the data estimating eq. (1) by feasible GLS. Thus, it is assumed that the error term $\varepsilon_{j t}$ in (1) can be decomposed as

$$
\varepsilon_{j t}=\omega_{j}+v_{j t}
$$

where $\omega_{j}$ denotes time-invariant country specific characteristics and $v_{j t}$ is the usual error term $v_{j t} \backsim I N\left(0, \sigma_{v}^{2}\right)$. The random effect estimation treats the country specific effects $\left(\omega_{j}\right)$ as random. The main disadvantage of this approach is that it requires the strong assumption of absence of correlation between the country specific characteristics and the set of covariates included in the regression. If this assumption is violated, the random effect estimators are inconsistent. Thus, as a robustness check this assumption is relaxed in a second set of regressions. Following Mundalk (1978), the orthogonality condition can be relaxed assuming that the country unobservable characteristics are a linear function of the average over time of the covariates. This amounts to rewriting $\omega_{j}$ in (2) as

$$
\omega_{j}=\delta_{0}+\bar{X}_{j} \delta_{1}+\eta_{j}
$$

where $\bar{X}_{j}$ is the individual mean of the time-varying covariates and $\eta_{j}$ is an unobservable component which is assumed to be uncorrelated with the $X_{j t}$. Collapsing (3) into (2) and substituting into (1) the resulting specification becomes

$$
l_{j t}=\phi_{0}+X_{j t} \beta+\bar{X}_{j} \delta_{1}+r_{j} \gamma+\eta_{j}+v_{j t} \quad \text { for } j=1,2 \ldots n \text { and } t=1,2 \ldots T_{j}
$$


where $\phi_{0}=\delta_{0}+\alpha$. In this case, the parameters $\beta$ corresponding to the time-varying covariates are forced to become closer to the fixed affect coefficients. Therefore, the orthogonality condition imposed by the random effects assumption is more likely to be met.

\subsection{The data}

The data set covers the period 1970-1998 for a maximum of 27 OECD countries depending on each specification. Five year averages are constructed to minimize the impact of short frequency fluctuations which are not the focus of this medium term analysis. ${ }^{6}$ The panel is slightly unbalanced, with 6 observations per country in most cases. Table 1 presents the main characteristics of the data. In the following, some of the variables included in the regression analysis are discussed. ${ }^{7}$

Income elasticity of demand and the productivity gap. GDP per capita measured in thousands of dollars and PPP exchange rates is introduced in all the regressions to control for the secular increase in the service employment share associated with demand and supply factors. GDP per capita squared is also introduced in order to capture non linearities in the relationship between both variables as those suggested by Figure 1. The use of PPP exchange rates avoids distortions due to large exchange rate fluctuations.

However, even if technological transfers are commonplace and presumably technology flows are faster today than ever, if imitation is costly (Barro and Sala i Martin, 1997) or countries raise barriers to technology adoption (Parente and Prescott, 1994) technology diffusion might be slower, and technological differences might be found even across countries with similar income per capita. Thus, in order to control for this factor and have a direct test for the service productivity gap, the ratio of manufacturing to service labour productivity is included in the regressions. ${ }^{8}$

Exogenous demand shifts. Government consumption as a percentage of GDP accounts for the size of the pubic sector. The urbanization rate (measured as the share of urban population in the total) accounts for exogenous demand shifts associated with the development of urban cultures, while the investment rate (measured as Gross fixed investment over GDP) accounts for possible composition effects of investment.

Labor market institutions. The OECD (1997) finds that more coordinated wage bargaining systems are associated with a relatively more compressed wage structure. Thus,

\footnotetext{
${ }^{6}$ This is also justified by the slow moving nature of institutions. See for instance, Blanchard and Wolfers (2000). The data are collapsed in five periods covering five-year intervals: 1970-1974, 1975-1979, 1980-1984, 1985-1989, 1990-1994 and one period of four years: 1995-1998.

${ }^{7}$ For precise definitions and sources see the data Appendix

${ }^{8}$ Productivity is measured as output per worker. A measure of hours worked in both sectors would be preferable, since different trends in part-time (probably more intense within the service sector) will contaminate the measure of relative productivities. Unfortunately, a long series of hours worked per sector for this large set of countries is not available.
} 
union density rates and an indicator of the degree of wage-setting co-ordination are included in the regressions as proxies for union bargaining power. Unemployment benefits could also raise wage floors by increasing the reservation wage of labour market participants. The replacement rate, measured as the percentage of unemployment benefits with respect to the previous wage, controls for the generosity of passive labour market policies. Alternatively, an indicator of wage compression (the ratio of the 50th to the 10th decile of the wage distribution) is considered in an attempt to control for the effects of wage floors on the development of service employment. An indicator of employment protection legislation controls for adjustment costs in the labour market.

Product market regulations. An index of administrative burdens to the creation of new firms controls for the effects of barriers to entry in the growth of service employment. This indicator refers to barriers to entry which are not only affecting the service sector but the whole economy, ranking the countries under study in a scale from 0 to 6 according to the increasing strictness of the regulations.

Trade specialization. The percentage of ores, fuel and raw materials exports with respect to GDP accounts for natural resources availability. Similarly, the ratio of services to manufacturing trade balances controls for direct trade specialization. Finally, in order to control for possible sources of comparative advantage due to differences in human capital, the percentage in the population holding a secondary school degree is included in the regressions.

Since the availability of data for specific countries and periods varies importantly depending on the control variable considered, the set of controls is divided into two groups. A core set of covariates is included in every specification according to data availability and their relative importance in explaining service employment. This basic specification includes GDP per capita, GDP per capita squared, administrative regulations, gross domestic fixed investment over GDP and the degree of urbanization. The remaining variables discussed above are introduced in separate specifications.

\section{Empirical Results}

Table 2 presents the results from the random effects estimations following eq. (1) and Table 3 presents the same specifications including time dummies. ${ }^{9}$ In all specifications,

\footnotetext{
${ }^{9}$ Panel unit root tests following the methodology proposed Maddala and Wu (1999) were implemented. This is a simple Fisher type test that combines information of unit root test for each separate crosssection. For all variables except GDP per capita, when no trend is included in the regression the null of unit root was rejected within our 5 year averages panel. The results were qualitatively the same using Philips-Perron or Augmented Dickey Fuller tests for each of the cross-sectional units $N$. The same test on the residuals of each specification rejected the null, suggesting the hypothesis of non-spurious regression and the appropriateness of stationary panel data estimation techniques. However, note that these results should be read very cautiously, given the reduced size of $T$ (6 in most cases) in the panel.
} 
the time dummies are jointly non-significant and results for the remaining variables are very similar when period dummies are dropped from the regression. Thus, I will concentrate in the text on the discussion of the regressions without time dummies (Table 2 ) and will only refer to the specification with time dummies when they alter the results. First note the Breusch-Pagan tests at the bottom of the table. In all cases, the absence of individual country effects is rejected. Similarly, the Hausman tests suggest that the hypothesis of consistency of the random effects estimates cannot be rejected in all the specifications that include the share of public sector consumption but exclude time dummies (columns 2 to 7 in Table 2)

Starting with the basic specification (Column 1), the first aspect worth noticing is the confirmation of the positive association between the service employment share and GDP per capita. This relationship has been widely documented in the past (see, for example, Maddison, 1980) and was recently confirmed by OECD (2000). The negative sign on the square of GDP per head points to a non linear relation between income per capita and the service employment share, suggesting a turning point when income per capita reaches $19,111 \$$. This is below the figures of the richest countries in the last period of the sample, implying that mature economies have entered a saturation point in the expansion of service employment. Indeed, there is a clear slowdown in the growth of the service employment share of the richest countries throughout the sample period. The counterpart of this deceleration, is a pattern of absolute convergence in the service employment share of OECD countries. This is illustrated in Figure 3, which shows a strong negative correlation (-.86) across countries between the average annual growth rate of the service employment share from 1970 to 1996 and the service employment share in 1970.

With reference to the role of some of the variables accounting for exogenous demand shifts, the indicator of urbanization is significant and signed as expected. According to the estimate of Column 1, a percentage point increase in the population living in urban areas would result in a 0.32 percentage points expansion of the service employment share. On the contrary, countries with a larger investment rate present a lower share of service employment. This is in line with the positive role of investment in the manufacturing employment share regressions found by Rowthorn and Ramaswamy (1999), and suggests that demand for investment is biased towards manufacturing goods. However, this effect becomes non-significant in 3 out of the 7 specifications when period dummies are included in the regressions.

The final regressor included in the core set of control variables is the indicator of administrative regulations. The negative and statistically significant effect supports the view that barriers to the creation of new firms have an asymmetric effect in the economy, by hindering the expansion of dynamic sectors within the service industries (Messina, 
2003). The size of the effect is considerable. According to the point estimate in Column 1, if administrative regulations for the creation of new firms in a country like Italy become as "market friendly" as in Canada, the service employment share in the European country would increase by more than 7 percentage points. ${ }^{10}$ The magnitude of the effect is somewhat lower in the remaining specifications, but negative and statistically significant in all cases except for the last column, where the sample size is reduced importantly due to the introduction of wage inequality as a regressor.

Column 2 introduces government consumption. Since a large fraction of government consumption represents the wage bill and public employees are concentrated on the service sector, there is a risk of artificially inflating the goodness of fit in the regressions when this indicator of the size of the public sector is included in the regressions. However, the effect does not seem to be present in the sample, with an adjusted $R^{2}$ of 0.86 both with and without government consumption in the regressions (Columns 1 and 2). ${ }^{11}$ This might be due to the fact that government consumption includes important expenditures not directly related to the size of the labour force in the public sector (such as intermediate consumption) but might also reflect the crowding out of private sector employment noted above. Moreover, introducing the share of public consumption proved important for the consistency of the estimators according to the Hausman test. Thus, this control is included in the remaining specifications. Accordingly, there is a clear positive association between the share of government consumption in GDP and the service employment share. This estimate, consistent with the positive association between the service employment share and the size of the welfare state found in OECD (2000), is very stable across all specifications and always statistically significant.

The results of the extended specifications are presented in Columns 3 to 7. According to Column 3, the productivity differential between manufacturing and services remains an important factor in explaining the expansion of service employment even after controlling for income per capita, supporting Baumol's hypothesis. Moreover, even after controlling for the service productivity gap the positive sign of GDP per capita remains highly significant, suggesting that demand factors cannot be disregarded as a source of service employment expansion.

The female employment share in Column 4 presents a positive (although non-significant) affect on the service employment share. Similarly, evidence in Columns 5 shows that trade specialization has a limited role in explaining the cross-country developments of

\footnotetext{
${ }^{10}$ This is just illustrative to give an idea of the magnitude of the effect. The Lucas critique would apply in such an event, rendering difficult to draw conclusions for deregulation policies from the analysis presented here.

${ }^{11}$ The share of current government expenditures in GDP is an alternative indicator commonly used in the literature to proxy for the size of the public sector. Results with this indicator, not reported in the text, do not differ qualitatively with respect to those with government consumption.
} 
service employment. The positive sign of the share of natural resources is in line with Dutch-disease hypothesis, while the direct measures of trade specialization and secondary education are also signed as expected. However, none of these estimates is statistically significant at the standard confidence levels. ${ }^{12}$

The last two columns in the table concentrate on the role played in the development of the service sector of several institutional aspects of the labour market. Dismissal restrictions, as measured by the OECD indices of employment protection legislation do not seem to affect service employment, contrasting with the evidence presented for a reduced sample in the OECD (2000). ${ }^{13}$ On the contrary, estimates in Column 6 indicate that the strength of union bargaining power, either when measured through union density or through the degree of wage-setting co-ordination, play an important role in the determination of service employment. According to these estimates, a 10 percentage points fall in the unionization rate, as happened within the sample period in Australia for instance, would have resulted in an expansion of service employment of 1 percentage point. This effect is reduced when period dummies are introduced, suggesting that the point estimate is capturing the effect of the de-unionization trend observed in most countries during the sample period. Regarding unemployment benefits, countries with more generous systems appear to have a larger service employment share, a somewhat puzzling result given the likely role of these institutions in rasing reservation wages. Finally, Column 7 presents an attempt to test directly for the role of wage compression in the development of the service sector. The indicator of wage inequality is signed as expected, suggesting that countries with more unequal wage distributions tend to have larger service employment shares. However, possibly due to the limited availability of information on the distribution of wages and the small sample at hand, this effect is not statistically significant.

The next set of regressions, presented in Table 4, relax the random effects assumption following eq. (4) by assuming that the country effects are a linear function of the average of the covariates. In general, the results are in line with previous estimates, suggesting the robustness of the random effect estimates presented before. Thus, the analysis confirms the positive impact of GDP per capita, the productivity differential, government consumption and the degree of urbanization on the service employment share. On the contrary, the results suggest important institutional constraints to the development of service employment. Barriers to the creation of new firms due to product market reg-

\footnotetext{
${ }^{12}$ Similar results were obtained with other indicators of human capital described in Barro and Lee (2000) such as the average number of years of schooling in the population or the share of population holding a tertiary degree.

${ }^{13}$ The evidence presented in the table refers to an indicator constucted first by Blanchard and Wolfers (2000) and then extended by Nickell and Nunziata (2000) which has a time dimension but refers to a more restrictive definition of EPL. Substituting this idicator with those used in OECD (2000) yielded similar results.
} 
ulations and more unionized and coordinated wage-setting structures within a country are associated with a lower service employment share.

Table 5 presents disaggregated analysis of the determinants of employment shares in 4 service branches: Wholesale and Retail Trade (Wholesale), Transport and Communications (Transport), Social and Personal Services (Social) and Financial, Business Services, Insurance and Real Estate activities (FIRE). It should be noted from the outset that this exercise does not intend to model the determinants of each of these service branches separately. Instead, it aims to shed some light on the channels through which the aggregate determinants uncovered in the previous analysis are altering the sectoral distribution of employment. Thus, the analysis is confined to those regressors that turned out significant in the specification presented in Column 6 in the previous Tables. Looking at particular service branches should also help us learn about the role of institutional aspects in the determination of service employment. For instance, if union bargaining power compress the wage structure hindering the expansion of low skilled jobs, the effects of union density and more centralized wage bargaining systems should fall more than proportionally in those sectors that are intensive in low skilled labour such as Wholesale and Retail Trade. Similarly, if entry regulations obstruct the creation of employment, their effects should be more evident in rapid growing sectors such as Financial and Business Services, Social and Personal Services and to a lesser extent Wholesale and Retail Trade. ${ }^{14}$

Regarding structural factors, the driving forces behind the expansion of service subbranches are quite similar to those explaining the aggregate increase of the service employment share. Notably, income per capita presents a positive impact on the expansion of services in all branches except Transports and Communications, while the size of the public sector and the degree of urbanization are positively associated with all service sub-branches except Financial and Business services. With respect to institutional factors, as expected administrative regulations have a negative impact in all sectors, but the coefficient is only significantly different from zero in the case of Financial and Business Services. Regarding the role of unions and wage-setting institutions, more unionized countries with a higher degree of wage-setting co-ordination present a lower Wholesale and Retail trade sector. The effect is statistically significant, supporting the view that these institutions are likely to obstruct the expansion of services intensive in low skilled labour. However, a somewhat counter-intuitive result is the positive and statistically significant coefficient of wage-setting co-ordination in the Transport and Communications regression.

\footnotetext{
${ }^{14}$ However, in Social and Personal services there is an important role of public employment which does not need to be affected by entry regulations.
} 
Table 6 aims to shed some light on the explanatory power of each of the regressors considered in the previous specifications. Moreover, it disentangles the partial contribution of each variable in explaining the within and between country variation in the data, by allowing for the following transformation

$$
l_{j t}=\alpha+\left(X_{j t}-\bar{X}_{j}\right) \beta+\bar{X}_{j} \delta+r_{j} \gamma+\varepsilon_{j t} \quad \text { for } j=1,2 \ldots n \text { and } t=1,2 \ldots T_{j}
$$

where $X_{j t}$ denotes for the set of time-varying explanatory variables and $\bar{X}_{j}$ is the individual mean of the time-varying covariates. The rest of the variables are defined as above. In particular, $r_{j}$ is a time-invariant indicator of administrative regulations affecting the creation of new firms. In this context, an analysis of covariance of equation (5) provides estimates of the partial contribution of the regressors to the explanation of the evolution of the service share over time (the vector of coefficients $\beta$ ) and to the explanation of the cross-country variability in the service employment share (the vector $\delta$ and the coefficient $\gamma)$. Note that each coefficient should be read as the direct contribution of a regressor to the explanation of the dependent variable taken the other regressors as given. Thus, a low partial $R^{2}$ for a particular regressor does not necessarily imply that the variable is not important for the determination of the service employment share, since its effect might be partially captured by the rest of the control variables. On the contrary, if the explanatory variables were uncorrelated among each other, the sum of partial $R^{2}$ would be equal to the model $R^{2}$.

Table 4 presents ANCOVA results of the determinants of the aggregate service employment share for the set of regressors which turned out consistently significant in the previous specifications. According to Column 1, there is a clear dominance of GDP per capita in explaining both the within and between variability of the service employment share, accounting for more than 25 per cent of the variance of the dependent variable. The degree of urbanization plays a prominent role in explaining cross-country differences, while the generalized increase in government consumption throughout the sample period explains about 1.1 of the variation over time of the service employment share. Finally, the results confirm the non-negligible effect of administrative regulations on the creation of new firms in explaining the relative underdevelopment of service employment in some countries, accounting for more than 4 per cent of the cross-sectional variance in the data. Column 2 includes the ratio of manufacturing to services productivity in the regression. Note the sharp decline in the partial $R^{2}$ of the remaining variables, suggesting a considerable amount of colinearity between this variable and the rest of the regressors, which renders difficult to draw definitive conclusions about its predictive power. The last column includes union density, wage-setting co-ordination and the replacement rate. In all cases, the main effects of institutions fall on the cross-country variation of the service employment share. However, the evolution over time of union density rates has also affected significantly the recent evolution of service employment in this sample of OECD countries. 


\section{Conclusions}

The expansion of service employment is unambiguously associated with the growth of living standards in modern economies. However, there are some countries which seem to be lagging behind in the process of tertiarization of employment. This paper documents the main regularities in the expansion of service employment within OECD countries in the period 1970-1998 and explores the likely sources of divergence in the service employment share across this relatively homogeneous group of countries. The paper places a special emphasis on the role that institutional aspects may play in hampering or stimulating the growth of service employment.

According to the panel regressions presented in the text, which are robust to a variety of specifications, the analysis confirms the positive impact of GDP per capita on the service employment share, although it also suggests that the richest countries in the sample might have reached a saturation level in the expansion of the demand for services. Similarly, the increasing size of the public sector and progressive urbanization of the population within the period of analysis appear as prominent factors in the expansion of the relative size of the service sector.

The results also suggest important institutional constraints to the development of service employment. Stringent barriers to the creation of new firms due to administrative burdens to business startups and more unionized and coordinated wage-setting structures within a country are associated with a lower service employment share. Regarding product market regulations, this result is in line with theoretical insights that suggest that product market regulations hinder the development of sectors whose demand is income elastic, such as Financial and Business Services or Social and Personal Services. This is partially supported in an empirical analysis of the determinants of four service branches. The disaggregated analysis also uncovers that the main negative effects of unions and coordinated wage-setting structures falls on Retail and Wholesale Trade. Taking into account that this sector is intensive in low skill labour, this can be read as supportive evidence that more unionized labour markets where bargaining takes place at a very centralized or coordinated level are cutting back low skilled jobs. 


\section{References}

[1] Barro, R. and J. Lee (2000). International Data on Educational Attainment Updates and Implications. NBER Working Paper no. 7911

[2] Barro, R. and X. Sala-i-Martin (1997). Technological Diffusion, Convergence, and Growth. Journal of Economic Growth 2(1): pages 1-26.

[3] Baumol, W. (1967). Macroeconomics of Unbalanced Growth: the Anatomy of Urban Crisis. American Economic Review 57, no. 4: 415-26.

[4] Bertola, G., F. Blau and L. Kahn (2002) Comparative Analysis of Labor Market Outcomes: Lessons for the US from International Long-Run Evidence, in A. Krueger and R. Solow, eds., The Roaring Nineties: Can Full Employment be sustained?. New York: Russell Sage

[5] Blanchard, O. and J. Wolfers (2000) The role of Shocks and Institutions in the rise of European Unemployment: the Aggregate Evidence. The Economic Journal 110(462): C1-33.

[6] Bertrand, M. and F. Kramarz (2002), Does Entry Regulation Hinder Job Creation? Evidence from the French Retail Industry. Quarterly Journal of Economics 67(4): 1369-1414.

[7] Clark, C. (1957). The conditions of economic progress. London: MacMillan.

[8] Díaz-Fuentes, D. (1999). On the Limits of Post-Industrial Society. Structural Change and Service Employment in Spain. International Review of Applied Economics 13, no. 1: 111-23.

[9] Freeman, R., and R. Schettkat. (1998). From McDonald's to McKinsey: Comparing German and US Employment and Wage Structures. Paper Presented at the Leverhulme II Conference "The Labor Market:Stocks and Flows". 28-29 September. Institute for Economics and Statistics, Oxford University.

[10] Fuchs, V. (1968) The Service Economy, edn. New York: National Bureau of Economic Research.

[11] Gordon, R. (1997). In there a Trade-off Between Unemployment and Productivity Growth in Unemployment Policy. ed.. de la Dehesa, G. and Snower, D. Cambridge UP.

[12] Jimeno, J. and D. Rodriguez Palenzuela (2002) Youth Unemployment in the OECD: Demographic Shifts, Labour Market Institutions, and Macroeconomic Shocks. ECB Working Paper Series, no. 155 
[13] Kuznets, S. (1966). Modern Economic Growth. USA: Yale University Press.

[14] Maddala, G. and S. Wu (1999) A Comparative Study of Unit Root Test with Panel Data and a New Simple Test. Oxford Bulletin of Economics and Statistics, Special Issue: 631-652

[15] Maddison, A. (1980) Economic Growth and Structural Change in the Advanced Countries. In: I. Leveson, (ed..) Western Economies in Transition: Structural Change and Adjustment Policies in Industrial Countries, pp. 41-60. Boulder: Westview Press.

[16] Messina, J. (2003) The role of Product Market Regulations in the Process of Structural Change. ECB Working Paper Series, no. 217

[17] Mundalk, Y. (1978). On the Pooling of Time Series and Cross Section Data. Econometrica, 46, pp. 69-86

[18] Nickell, S. (1997) Unemployment and Labor Market Rigidities: Europe versus North America. The Journal of Economic Perspectives 11(3): 55-74

[19] Nickell, S. and L. Nunziata (2001) Employment Patterns in OECD Countries. Centre for Economic Performance Discussion Paper no. 448.

[20] Nicoletti, G., S. Scarpetta, and O. Boylaud. (1999), Summary Indicators of Product Market Regulation with an Extension to the Employment Protection Legislation. OECD Economic Department Working Papers, no. 226.

[21] Nicoletti, G., R. Haffner, S. Nickell, S. Scarpetta and G. Zoega (2000), European Integration, Liberalization and Labor Market Performance, in G. Bertola, T. Boeri and G. Nicoletti (eds.) Welfare and Employment in a United Europe, Harvard: MIT Press.

[22] OECD (2000) Employment in the Service Economy: a Reassessment. in Employment Outlook. Chapter 3. Paris.

[23] — (1997) Economic Performance and the Structure of Collective Bargaining. in, Employment Outlook. Chapter 3. Paris.

[24] Parente, S. and E. Prescott (1994) Barriers to Technology Adoption and Development. Journal of Political Economy 102(2): 298-321

[25] Piketty, T. (1998). L'emploi dans les services en France et aux Etats-Unis: une analyse structurelle sur longue période. Economie et Statistique 318: pp.73-99. 
[26] Rowthorn, R. and R. Ramaswamy. (1999). Growth, Trade and Deindustrialization. IMF Staff Papers 46, no. 1: 63-96.

[27] Saeger, S. (1997). Globalization and Deindustrialization: Myth and Reality in the OECD. Weltwirtschaftliches Archiv. 133, no. 4: 580-608.

[28] Scarpetta, S. (1996) Assessing the Role of Labour Market Policies and Institutional Settings on Unemployment: a Cross-Country Study, OECD Economic Studies, 26(1) 


\section{Appendix}

\section{Definition of the Variables and Data Sources}

Source: OECD Statistical Compendium (2001)

- Service Employment Share: Civilian service employment share in total civilian employment. Services are defined as ISIC Major Divisions 6 to 9, therefore including ISIC 6: wholesale and retail trade, restaurants and hotels, ISIC 7: transport, storage and communication, ISIC 8: financing, insurance, real estate, and business services and ISIC 9: community, social and personal services.

- Wholesale and retail employment share: ISIC 6 employment/total civilian employment

- Transport and Communications employment share: ISIC 7 employment/total civilian employment

- FIRE employment share: ISIC 8 employment/total civilian employment

- Community services employment share: ISIC 9 employment/total civilian employment

- GDP per capita: GDP per head at current prices and PPP exchange rates.

- Gov. Cons.: Government consumption expenditure over GDP.

- Female Emplo.: Female civilian employment as a share of total civilian employment.

- Productivity Diff.: Manufacturing labour productivity/Services labour productivity. Labor productivity is defined as sectoral GDP at constant prices/Total Employment.

- Tax wedge: Average tax burden as a percentage of GDP.

- Trade ratio. Manufacturing trade balance over services trade balance.

Source: World Development Indicators (2001)

- Investment: Gross domestic fixed investment over GDP.

- Urbanization: Urban population as percentage of total population.

- Natural Res. Exp.. Natural resources exports as percentage of GDP. Natural resources include fuels, ores, metal and raw material exports. 
Source: Nicoletti et al. (1999)

- Administrative Reg. Administrative regulations to business startups. This indicator illustrates the relative stringency of product market regulations in OECD countries for a point in time referring to the end of the 1990s, ranking countries from 0 to 6 according to increasing stringency of the regulatory standards. The variable included in the regression is constructed under the assumption of constancy of this institutions in the period of analysis.

Source: OECD DEELSEA Earnings Structure Database

- Wage ineq.: Ratio of the 50th to the 10th percentile of the earnings distribution. Generally, they refer to gross earnings rations, except for France. They normally refer to full-time full-year earnings, except for Austria, Denmark and Norway, which include all employees. Earnings are defined on an annual basis in Canada, Finland, France, the Netherlands, Spain, Sweden and Switzerland; monthly in Austria, the Czech Republic, Germany, Hungary, Italy, Japan, Korea and Poland; weekly in Australia, Belgium, Ireland, New Zealand, Portugal, the United Kingdom and the United States; hourly in Norway.

Source: Nickell and Nunziata (2001). Labour Market Institutions database

- EPL: Employment protection legislation for regular and temporary contracts.

- Union Density: Net (gross minus retired and unemployed members) union density rate

- Co-ordination: Wage-setting co-ordination. Index with range $\{1,3\}$ increasing in the degree of co-ordination

- Replacement Rt.: Average unemployment benefit received in the first year of unemployment as a fraction of average earnings before taxes.

Source: Barro and Lee (2000)

- Secondary Edu.: Percentage of secondary school completed in total population. 
Table 1: Summary Statistics

\begin{tabular}{lcccccc}
\hline \hline Variable & Mean & St. Dv. & Min. & Max. & N.Ob. & N.C. \\
\hline & & & & & & \\
Service Employment Share & 56.04 & 11.53 & 20.89 & 73.84 & 143 & 27 \\
GDP per Capita & 11.03 & 6.57 & 0.83 & 27.96 & 143 & 27 \\
Administrative Reg. & 1.99 & 0.88 & 0.50 & 3.90 & 143 & 27 \\
Gov. Cons. & 16.75 & 4.72 & 7.56 & 29.05 & 143 & 27 \\
Investment & 22.50 & 4.59 & 13.68 & 36.77 & 143 & 27 \\
Urbanization & 70.87 & 14.79 & 26.60 & 97.00 & 143 & 27 \\
Productivity Diff. & 0.70 & 0.22 & 0.39 & 1.42 & 117 & 23 \\
Female Emplo. & 50.33 & 12.58 & 20.13 & 77.66 & 134 & 27 \\
Secundary Edu. & 20.52 & 11.58 & 3.80 & 47.50 & 90 & 24 \\
Trade Ratio & 100.6 & 36.38 & 38.13 & 264.0 & 90 & 24 \\
Natural Res. Exp. & 3.70 & 3.91 & 0.17 & 18.73 & 90 & 24 \\
EPL & 1.07 & 0.57 & 0.10 & 2.00 & 114 & 20 \\
Union Density & 43.83 & 19.43 & 9.00 & 90.0 & 114 & 20 \\
Co-ordination & 2.09 & 0.59 & 1.00 & 3.00 & 114 & 20 \\
Replacement Rt. & 0.43 & 0.18 & 0.02 & 0.77 & 114 & 20 \\
Wage ineq. & 1.69 & 0.24 & 1.31 & 2.41 & 76 & 23 \\
\hline \hline
\end{tabular}

Note: For the core set of regressors (GDP per capita, Administrative Regulations, Government Consumption, Fixed Investment and the Urbanization Rate) the summary statistics refer to the sample included in the basic specification. The summary statistics for the other variables refer to the specific samples used in each of the regressions. N.Ob.: number of observations. N.C.: Number of countries. 
Table 2: The Determinants of Service Employment. 1970-1998. Random Effects

\begin{tabular}{|c|c|c|c|c|c|c|c|}
\hline & \multicolumn{7}{|c|}{ Dependent Variable: Service Employment Share } \\
\hline Model : & 1 & 2 & 3 & 4 & 5 & 6 & 7 \\
\hline Constant & $\begin{array}{c}31.66 \ddagger \\
(3.31)\end{array}$ & $\begin{array}{c}24.24 \ddagger \\
(4.05)\end{array}$ & $\begin{array}{c}22.29 \ddagger \\
(4.64)\end{array}$ & $\begin{array}{r}24.86 \ddagger \\
(5.37)\end{array}$ & $\begin{array}{c}25.60 \ddagger \\
(4.80)\end{array}$ & $\begin{array}{l}34.31 \ddagger \\
(5.98)\end{array}$ & $\begin{array}{c}32.72 \ddagger \\
(8.63)\end{array}$ \\
\hline GDP per capita & $\begin{array}{c}1.72 \ddagger \\
(0.12)\end{array}$ & $\begin{array}{c}1.55 \ddagger \\
(0.13)\end{array}$ & $\begin{array}{c}1.54 \ddagger \\
(0.17)\end{array}$ & $\begin{array}{c}1.52 \ddagger \\
(0.15)\end{array}$ & $\begin{array}{c}2.19 \ddagger \\
(0.21)\end{array}$ & $\begin{array}{c}1.36 \ddagger \\
(0.12)\end{array}$ & $\begin{array}{c}1.64 \ddagger \\
(0.16)\end{array}$ \\
\hline$(\text { GDP per capita })^{2}$ & $\begin{array}{c}-0.03 \ddagger \\
(0.00)\end{array}$ & $\begin{array}{c}-0.03 \ddagger \\
(0.00)\end{array}$ & $\begin{array}{l}-0.03 \ddagger \\
(0.00)\end{array}$ & $\begin{array}{r}-0.03 \ddagger \\
(0.00)\end{array}$ & $\begin{array}{c}-0.04 \ddagger \\
(0.01)\end{array}$ & $\begin{array}{r}-0.02 \ddagger \\
(0.00)\end{array}$ & $\begin{array}{r}-0.03 \ddagger \\
(0.01)\end{array}$ \\
\hline Admin. Reg. & $\begin{array}{r}-3.51 \ddagger \\
(0.96)\end{array}$ & $\begin{array}{r}-2.61 \ddagger \\
(1.03)\end{array}$ & $\begin{array}{l}-2.30 \ddagger \\
(1.18)\end{array}$ & $\begin{array}{c}-2.59 \ddagger \\
(1.06)\end{array}$ & $\begin{array}{r}-2.04 \ddagger \\
(0.97)\end{array}$ & $\begin{array}{l}-2.09 \dagger \\
(1.25)\end{array}$ & $\begin{array}{l}-1.53 \\
(1.06)\end{array}$ \\
\hline Investment & $\begin{array}{c}-0.23 \ddagger \\
(0.07)\end{array}$ & $\begin{array}{c}-0.17 \ddagger \\
(0.07)\end{array}$ & $\begin{array}{l}-0.09 \\
(0.08)\end{array}$ & $\begin{array}{c}-0.17 \dagger \\
(0.09)\end{array}$ & $\begin{array}{r}-0.21 \ddagger \\
(0.08)\end{array}$ & $\begin{array}{c}-0.20 \ddagger \\
(0.08)\end{array}$ & $\begin{array}{c}-0.40 \ddagger \\
(0.09)\end{array}$ \\
\hline Urbanization & $\begin{array}{c}0.32 \ddagger \\
(0.04)\end{array}$ & $\begin{array}{c}0.31 \ddagger \\
(0.04)\end{array}$ & $\begin{array}{c}0.22 \ddagger \\
(0.05)\end{array}$ & $\begin{array}{c}0.29 \ddagger \\
(0.06)\end{array}$ & $\begin{array}{c}0.16 \ddagger \\
(0.05)\end{array}$ & $\begin{array}{c}0.25 \ddagger \\
(0.06)\end{array}$ & $\begin{array}{c}0.27 \ddagger \\
(0.05)\end{array}$ \\
\hline Gov. Cons. & & $\begin{array}{c}0.36 \ddagger \\
(0.12)\end{array}$ & $\begin{array}{c}0.39 \ddagger \\
(0.14)\end{array}$ & $\begin{array}{c}0.37 \ddagger \\
(0.12)\end{array}$ & $\begin{array}{c}0.50 \ddagger \\
(0.13)\end{array}$ & $\begin{array}{c}0.50 \ddagger \\
(0.13)\end{array}$ & $\begin{array}{c}0.10 \\
(0.15)\end{array}$ \\
\hline Productivity Diff. & & & $\begin{array}{c}7.99 \ddagger \\
(2.19)\end{array}$ & & & & \\
\hline Female Emplo. & & & & $\begin{array}{c}0.02 \\
(0.04)\end{array}$ & & & \\
\hline Trade ratio & & & & & $\begin{array}{c}0.01 \\
(0.01)\end{array}$ & & \\
\hline Natural Res Exp. & & & & & $\begin{array}{c}0.25 \\
(0.14)\end{array}$ & & \\
\hline Secondary Edu. & & & & & $\begin{array}{c}-0.04 \\
(0.03)\end{array}$ & & \\
\hline EPL & & & & & & $\begin{array}{l}-0.97 \\
(0.98)\end{array}$ & \\
\hline Union Density & & & & & & $\begin{array}{c}-0.10 \ddagger \\
(0.02)\end{array}$ & \\
\hline Co-ordination & & & & & & $\begin{array}{r}-0.92 \ddagger \\
(0.45)\end{array}$ & \\
\hline Replacement Rt. & & & & & & $\begin{array}{c}3.46 \ddagger \\
(1.65)\end{array}$ & \\
\hline Wage ineq. & & & & & & & $\begin{array}{c}1.58 \\
(2.79)\end{array}$ \\
\hline Period dummies & No & No & No & No & No & No & No \\
\hline BP Test $\left(P>\chi^{2}\right)$ & $0.00 \ddagger$ & $0.00 \ddagger$ & $0.00 \ddagger$ & $0.00 \ddagger$ & $0.00 \ddagger$ & $0.00 \ddagger$ & $0.00 \ddagger$ \\
\hline Hausman $\left(P>\chi^{2}\right)$ & $0.00 \ddagger$ & 0.37 & 0.59 & 0.54 & 0.21 & 0.21 & 0.59 \\
\hline$R^{2}$ & 0.86 & 0.86 & 0.89 & 0.82 & 0.87 & 0.83 & 0.80 \\
\hline Number Obs. & 143 & 143 & 117 & 134 & 90 & 114 & 76 \\
\hline
\end{tabular}

Note: Standard errors in parenthesis. $\ddagger$ and $\dagger$ denote statistically significant at the $5 \%$ and $10 \%$ levels respectively. 
Table 3: Random Effects Including Time Dummies

\begin{tabular}{|c|c|c|c|c|c|c|c|}
\hline & \multicolumn{7}{|c|}{ Dependent Variable: Service Employment Share } \\
\hline Model : & 1 & 2 & 3 & 4 & 5 & 6 & 7 \\
\hline \multirow[t]{2}{*}{ Constant } & $32.98 \ddagger$ & $24.67 \ddagger$ & $20.14 \ddagger$ & $22.62 \ddagger$ & $32.75 \ddagger$ & $40.90 \ddagger$ & $30.90 \ddagger$ \\
\hline & $(4.36)$ & $(4.99)$ & $(5.29)$ & $(5.77)$ & $(6.24)$ & $(6.26)$ & $(9.07)$ \\
\hline \multirow[t]{2}{*}{ GDP per capita } & $1.90 \ddagger$ & $1.73 \ddagger$ & $2.12 \ddagger$ & $1.93 \ddagger$ & $1.88 \ddagger$ & $0.74 \ddagger$ & $1.70 \ddagger$ \\
\hline & $(0.25)$ & $(0.24)$ & $(0.31)$ & $(0.28)$ & $(0.29)$ & $(0.31)$ & $(0.35)$ \\
\hline \multirow[t]{2}{*}{$(\text { GDP per capita })^{2}$} & $-0.04 \ddagger$ & $-0.04 \ddagger$ & $-0.05 \ddagger$ & $-0.04 \ddagger$ & $-0.04 \ddagger$ & $-0.02 \ddagger$ & $-0.04 \ddagger$ \\
\hline & $(0.01)$ & $(0.01)$ & $(0.01)$ & $(0.01)$ & $(0.01)$ & $(0.01)$ & $(0.01)$ \\
\hline \multirow[t]{2}{*}{ Admin. Reg. } & $-3.50 \ddagger$ & $-2.41 \ddagger$ & $-2.12 \ddagger$ & $-2.29 \ddagger$ & $-2.31 \ddagger$ & $-2.16 \ddagger$ & -1.05 \\
\hline & $(0.89)$ & $(0.95)$ & $(0.96)$ & $(0.99)$ & (1.11) & (1.11) & $(1.20)$ \\
\hline \multirow[t]{2}{*}{ Investment } & $-0.22 \ddagger$ & $-0.15 \dagger$ & -0.12 & -0.16 & $-0.20 \ddagger$ & -0.06 & $-0.38 \ddagger$ \\
\hline & $(0.06)$ & $(0.07)$ & $(0.08)$ & $(0.09)$ & $(0.08)$ & $(0.07)$ & $(0.09)$ \\
\hline \multirow[t]{2}{*}{ Urbanization } & $0.30 \ddagger$ & $0.28 \ddagger$ & $0.21 \ddagger$ & $0.25 \ddagger$ & $0.13 \ddagger$ & $0.26 \ddagger$ & $0.23 \ddagger$ \\
\hline & $(0.04)$ & $(0.04)$ & $(0.04)$ & $(0.05)$ & $(0.05)$ & $(0.05)$ & $(0.06)$ \\
\hline \multirow[t]{2}{*}{ Gov. Cons. } & & $0.43 \ddagger$ & $0.39 \ddagger$ & $0.45 \ddagger$ & $0.60 \ddagger$ & $0.50 \ddagger$ & 0.25 \\
\hline & & $(0.12)$ & $(0.14)$ & $(0.12)$ & $(0.13)$ & $(0.11)$ & $(0.16)$ \\
\hline Productivity Diff. & & & $\begin{array}{c}7.60 \ddagger \\
(2.19)\end{array}$ & & & & \\
\hline Female Emplo & & & & $\begin{array}{c}0.03 \\
(0.04)\end{array}$ & & & \\
\hline Trade ratio & & & & & 0.01 & & \\
\hline \multirow{2}{*}{ Natural Res. Exp. } & & & & & $\begin{array}{c}(0.01) \\
0.21\end{array}$ & & \\
\hline & & & & & $(0.15)$ & & \\
\hline \multirow[t]{2}{*}{ Secondary Edu. } & & & & & -0.04 & & \\
\hline & & & & & $(0.03)$ & & \\
\hline \multirow[t]{2}{*}{ EPL } & & & & & & -0.77 & \\
\hline & & & & & & $(0.89)$ & \\
\hline \multirow[t]{2}{*}{ Union Density } & & & & & & $-0.07 \ddagger$ & \\
\hline & & & & & & $(0.02)$ & \\
\hline \multirow[t]{2}{*}{ Co-ordination } & & & & & & -0.35 & \\
\hline & & & & & & $(0.42)$ & \\
\hline \multirow[t]{2}{*}{ Replacement Rt. } & & & & & & $3.76 \ddagger$ & \\
\hline & & & & & & $(1.44)$ & \\
\hline \multirow[t]{2}{*}{ Wage ineq. } & & & & & & & 2.78 \\
\hline & & & & & & & $(2.89)$ \\
\hline Period Dummies & Yes & Yes & Yes & Yes & Yes & Yes & Yes \\
\hline $\mathrm{BP}$ Test $\left(P>\chi^{2}\right)$ & $0.00 \ddagger$ & $0.00 \ddagger$ & $0.00 \ddagger$ & $0.00 \ddagger$ & $0.00 \ddagger$ & $0.00 \ddagger$ & $0.00 \ddagger$ \\
\hline $\operatorname{Hausman}\left(P>\chi^{2}\right)$ & $0.00 \ddagger$ & $0.00 \ddagger$ & $0.00 \ddagger$ & $0.00 \ddagger$ & $0.00 \ddagger$ & $0.00 \ddagger$ & $0.00 \ddagger$ \\
\hline$R^{2}$ & 0.86 & 0.86 & 0.89 & 0.83 & 0.82 & 0.79 & 0.76 \\
\hline N. obs: & 143 & 143 & 117 & 134 & 90 & 114 & 76 \\
\hline
\end{tabular}

Note: Standard errors in parenthesis. $\ddagger$ and $\dagger$ denote statistically significant at the $5 \%$ and $10 \%$ levels respectively. 
Table 4: The determinants of Service Employment. 1970-1998. Mundalk Specification

\begin{tabular}{|c|c|c|c|c|c|c|c|}
\hline \multirow{2}{*}{ Model : } & & \multicolumn{6}{|c|}{ "Dependent Variable: Service Employment Share } \\
\hline & 1 & 2 & 3 & 4 & 5 & 6 & 7 \\
\hline \multirow[t]{2}{*}{ Constant } & $30.41 \ddagger$ & $30.97 \ddagger$ & $15.90 \ddagger$ & $34.88 \ddagger$ & $27.77 \ddagger$ & $42.08 \dagger$ & $39.28 \ddagger$ \\
\hline & $(9.48)$ & $(10.54)$ & $(14.45)$ & $(9.52)$ & $(8.77)$ & $(19.64)$ & $(14.38)$ \\
\hline \multirow[t]{2}{*}{ GDP per capita } & $1.66 \ddagger$ & $1.47 \ddagger$ & $1.58 \ddagger$ & $1.43 \ddagger$ & $2.06 \ddagger$ & $1.27 \ddagger$ & $1.59 \ddagger$ \\
\hline & $(0.14)$ & $(0.14)$ & $(0.19)$ & $(0.16)$ & $(0.23)$ & $(0.12)$ & $(0.17)$ \\
\hline \multirow[t]{2}{*}{$(\text { GDP per capita })^{2}$} & $-0.03 \ddagger$ & $-0.03 \ddagger$ & $-0.04 \ddagger$ & $-0.03 \ddagger$ & $-0.04 \ddagger$ & $-0.02 \ddagger$ & $-0.03 \ddagger$ \\
\hline & $(0.00)$ & $(0.00)$ & $(0.01)$ & $(0.01)$ & $(0.01)$ & $(0.00)$ & $(0.01)$ \\
\hline \multirow[t]{2}{*}{ Admin.. Reg. } & $-3.73 \ddagger$ & $-3.79 \ddagger$ & $-2.75 \ddagger$ & $-3.77 \ddagger$ & $-2.63 \ddagger$ & -2.50 & $-2.89 \dagger$ \\
\hline & $(1.12)$ & $(1.22)$ & $(1.50)$ & $(1.26)$ & (1.13) & $(1.74)$ & $(1.25)$ \\
\hline \multirow[t]{2}{*}{ Investment } & $-0.29 \ddagger$ & $-0.20 \ddagger$ & -0.04 & $-0.18 \ddagger$ & $-0.23 \ddagger$ & $-0.20 \ddagger$ & $-0.47 \ddagger$ \\
\hline & $(0.08)$ & $(0.08)$ & $(0.10)$ & $(0.09)$ & $(0.10)$ & $(0.08)$ & $(0.10)$ \\
\hline \multirow[t]{2}{*}{ Urbanization } & $0.36 \ddagger$ & $0.34 \ddagger$ & $0.16 \dagger$ & $0.31 \ddagger$ & 0.09 & $0.49 \ddagger$ & $0.36 \ddagger$ \\
\hline & $(0.06)$ & $(0.05)$ & $(0.07)$ & $(0.10)$ & $(0.09)$ & $(0.14)$ & $(0.09)$ \\
\hline \multirow[t]{2}{*}{ Gov. Cons. } & & $0.44 \ddagger$ & $0.46 \ddagger$ & $0.47 \ddagger$ & $0.80 \ddagger$ & $0.50 \ddagger$ & $0.22 \ddagger$ \\
\hline & & $(0.13)$ & $(0.16)$ & $(0.14)$ & $(0.17)$ & $(0.14)$ & $(0.19)$ \\
\hline \multicolumn{2}{|l|}{ Productivity Diff. } & & $\begin{array}{l}9.17 \ddagger \\
(2.48)\end{array}$ & & & & \\
\hline Female Emplo. & & & & $\begin{array}{c}0.03 \\
(0.05)\end{array}$ & & & \\
\hline \multirow[t]{2}{*}{ Trade ratio } & & & & & 0.01 & & \\
\hline & & & & & $(0.01)$ & & \\
\hline \multirow[t]{2}{*}{ Natural Res. Exp. } & & & & & 0.02 & & \\
\hline & & & & & $(0.18)$ & & \\
\hline \multirow[t]{2}{*}{ Secondary Educ. } & & & & & -0.05 & & \\
\hline & & & & & $(0.03)$ & & \\
\hline \multirow[t]{2}{*}{ EPL } & & & & & & -0.66 & \\
\hline & & & & & & $(1.14)$ & \\
\hline \multirow[t]{2}{*}{ Union Density } & & & & & & $-0.12 \ddagger$ & \\
\hline & & & & & & $(0.03)$ & \\
\hline \multirow[t]{2}{*}{ Co-ordination } & & & & & & $-1.02 \dagger$ & \\
\hline & & & & & & $(0.45)$ & \\
\hline \multirow[t]{2}{*}{ Replacement Rt. } & & & & & & 2.12 & \\
\hline & & & & & & $(1.76)$ & \\
\hline \multirow[t]{2}{*}{ Wage ineq. } & & & & & & & 6.31 \\
\hline & & & & & & & $(4.36)$ \\
\hline$R^{2}$ & 0.89 & 0.89 & 0.91 & 0.87 & 0.92 & 0.90 & 0.83 \\
\hline N. obs: & 143 & 143 & 117 & 134 & 90 & 114 & 76 \\
\hline
\end{tabular}

Note: Standard errors in parenthesis. $\ddagger$ and $\dagger$ denote statistically significant at the $5 \%$ and $10 \%$ levels respectively. All the regressions include (not reported in the table) the cross-sectional average of the time variant covariates. 
Table 5: Institutions and Structural Factors on Employment Shares of Service Branches in OECD Countries. 1970-1998

\begin{tabular}{lcccc}
\hline \hline Model : & 1 & 2 & 3 & 4 \\
\hline Depvar: & Wholesale & Transport & Social & FIRE \\
\hline Constant & $18.567 \ddagger$ & 1.309 & $11.40 \ddagger$ & $5.186 \dagger$ \\
& $(3.654)$ & $(1.465)$ & $(4.863)$ & $(2.857)$ \\
GDP per capita & $0.324 \ddagger$ & -0.051 & $0.616 \ddagger$ & $0.392 \ddagger$ \\
& $(0.087)$ & $(0.034)$ & $(0.120)$ & $(0.072)$ \\
(GDP per capita) ${ }^{2}$ & $-0.007 \ddagger$ & 0.001 & $-0.014 \ddagger$ & -0.004 \\
& $(0.003)$ & $(0.001)$ & $(0.004)$ & $(0.002)$ \\
Gov. Consumption & 0.108 & $0.087 \ddagger$ & $0.310 \ddagger$ & 0.001 \\
& $(0.089)$ & $(0.035)$ & $(0.122)$ & $(0.072)$ \\
Urbanization & 0.028 & $0.030 \ddagger$ & $0.130 \ddagger$ & 0.033 \\
& $(0.034)$ & $(0.014)$ & $(0.044)$ & $(0.025)$ \\
Investment & 0.020 & 0.037 & $-0.238 \ddagger$ & -0.038 \\
& $(0.058)$ & $(0.023)$ & $(0.079)$ & $(0.046)$ \\
Administrative. Reg. & -0.920 & -0.107 & -0.423 & $-1.061 \ddagger$ \\
& $(0.668)$ & $(0.271)$ & $(0.864)$ & $(0.498)$ \\
Union Density & $-0.097 \ddagger$ & 0.003 & 0.021 & $-0.029 \ddagger$ \\
& $(0.017)$ & $(0.007)$ & $(0.023)$ & $(0.014)$ \\
Co-ordination & $-0.667 \ddagger$ & $0.462 \ddagger$ & -0.534 & -0.166 \\
& $(0.314)$ & $(0.124)$ & $(0.435)$ & $(0.251)$ \\
Replacement Rt. & -0.016 & 0.142 & $3.568 \ddagger$ & 0.853 \\
& $(1.141)$ & $(0.450)$ & $(1.570)$ & $(0.925)$ \\
\hline Hausman Test $\left(P>\chi^{2}\right)$ & $0.01 \ddagger$ & 0.99 & 0.38 & 0.69 \\
N. obs: & 110 & 110 & 110 & 102 \\
$\mathrm{R}^{2}$ & 0.475 & 0.401 & 0.746 & 0.731 \\
\hline \hline
\end{tabular}

Note: Standard errors in parenthesis. $\ddagger$ and $\dagger$ denote statistically significant at the $5 \%$ and $10 \%$ levels respectively. 
Table 6: Analysis of Covariance. Cross-country Determinants of Service Employment Share in OECD Countries. 1970-1998

\begin{tabular}{|c|c|c|c|c|c|c|}
\hline & \multicolumn{2}{|c|}{ (1) } & \multicolumn{2}{|c|}{$(2)$} & \multicolumn{2}{|c|}{$(3)$} \\
\hline & Par $\mathrm{R}^{2}$ & $\operatorname{Pr}>F$ & Par $\mathrm{R}^{2}$ & $\operatorname{Pr}>F$ & Par R $^{2}$ & $\operatorname{Pr}>F$ \\
\hline \multicolumn{7}{|c|}{ Within-Country Variation } \\
\hline GDP per capita & 10.52 & $(0.00)$ & 2.370 & $(0.00)$ & 8.446 & $(0.00)$ \\
\hline Government Cons. & 1.129 & $(0.00)$ & 1.118 & $(0.00)$ & 1.081 & $(0.00)$ \\
\hline Urbanization & 1.355 & $(0.00)$ & 0.810 & $(0.00)$ & 0.532 & $(0.01)$ \\
\hline Produ & - & - & 0.215 & $(0.09)$ & - & - \\
\hline Unior & - & - & - & - & 0.479 & $(0.02)$ \\
\hline $\mathrm{Co}-\mathrm{Ol}$ & - & - & - & - & 0.110 & $(0.25)$ \\
\hline Replacement Rt. & - & - & - & - & 0.016 & $(0.66)$ \\
\hline \multicolumn{7}{|c|}{ Cross-Country Variation } \\
\hline Administrative Reg. & 4.022 & $(0.00)$ & 1.811 & $(0.00)$ & 4.336 & $(0.00)$ \\
\hline GDP per $c$ & 14.85 & $(0.00)$ & 7.664 & $(0.00)$ & 12.19 & $(0.00)$ \\
\hline Government Cons. & 0.022 & $(0.57)$ & 0.033 & $(0.51)$ & 0.581 & $(0.01)$ \\
\hline Urbar & 6.194 & $(0.00)$ & 2.558 & $(0.00)$ & 10.18 & $(0.00)$ \\
\hline Productivity Diff. & - & - & 1.641 & $(0.00)$ & - & - \\
\hline UnionDensity & - & - & - & - & 1.366 & $(0.00)$ \\
\hline Co-or & - & - & - & - & 0.845 & $(0.00)$ \\
\hline Replacement Rt. & - & - & - & - & 2.831 & $(0.00)$ \\
\hline Overall Fit & 90.09 & $(0.00)$ & 91.42 & $(0.00)$ & 91.26 & $(0.00)$ \\
\hline
\end{tabular}

Note: $\operatorname{Pr}>\mathrm{F}$ is the probability of accpeting the null of $\beta=0$ 


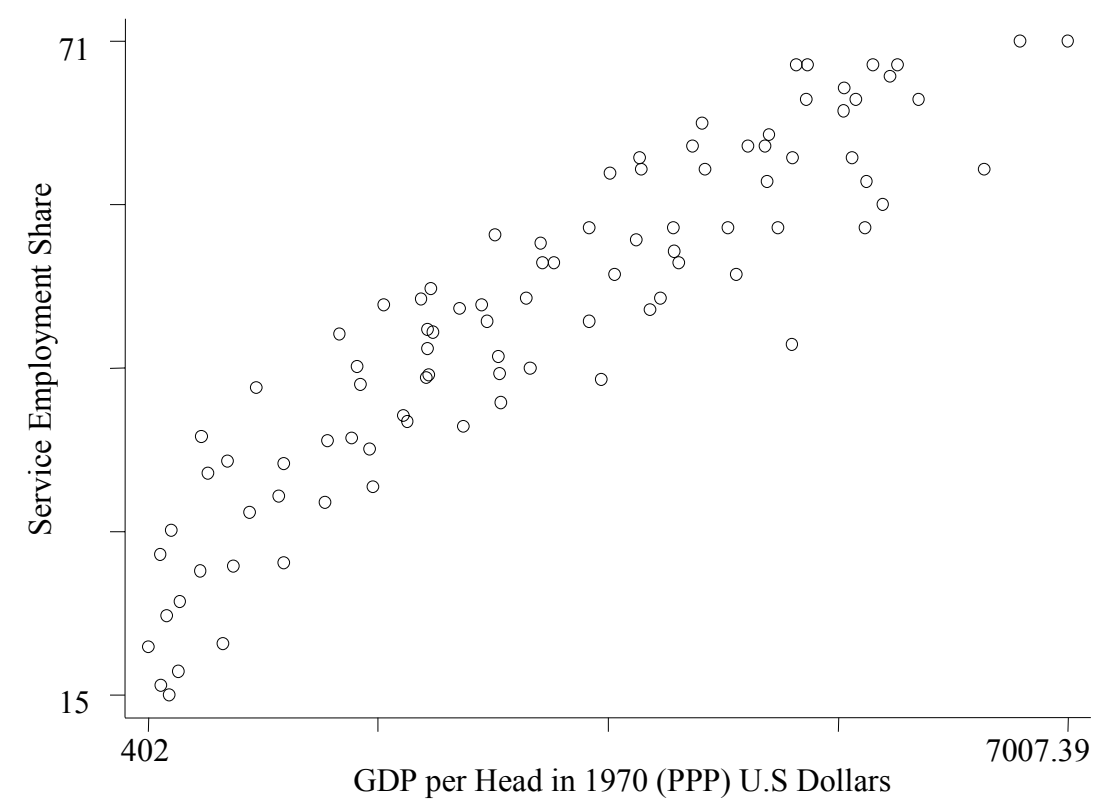

-Sources: Real GDP per capita: 1870-1960 from Maddison (1980) and 1970-1990 from Penn World Table 5.6, converted to 1970 U.S dollars using the GDP deflator from the OECD Statistical Compendium (1999).

-Service Share of Employment: 1870-1960 from Maddison (1980) and 1970-1990 from OECD (1999).

- Countries included: Australia, Belgium, Canada, Denmark, Finland, France, Germany, Italy, Japan, The Netherlands, Norway, Sweden, U.K and the United States.

Figure 1: Service Employment and GDP per Capita. 14 OECD Countries. 1870-1990 


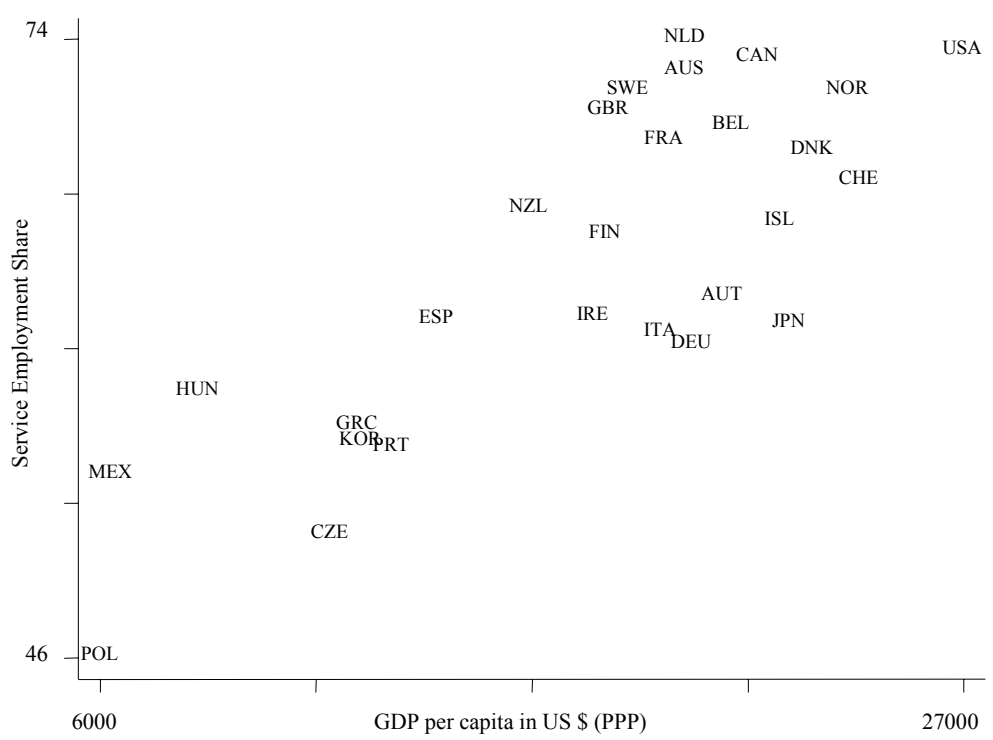

Figure 2: Average Service Employment and Income per Capita. 1995-1998

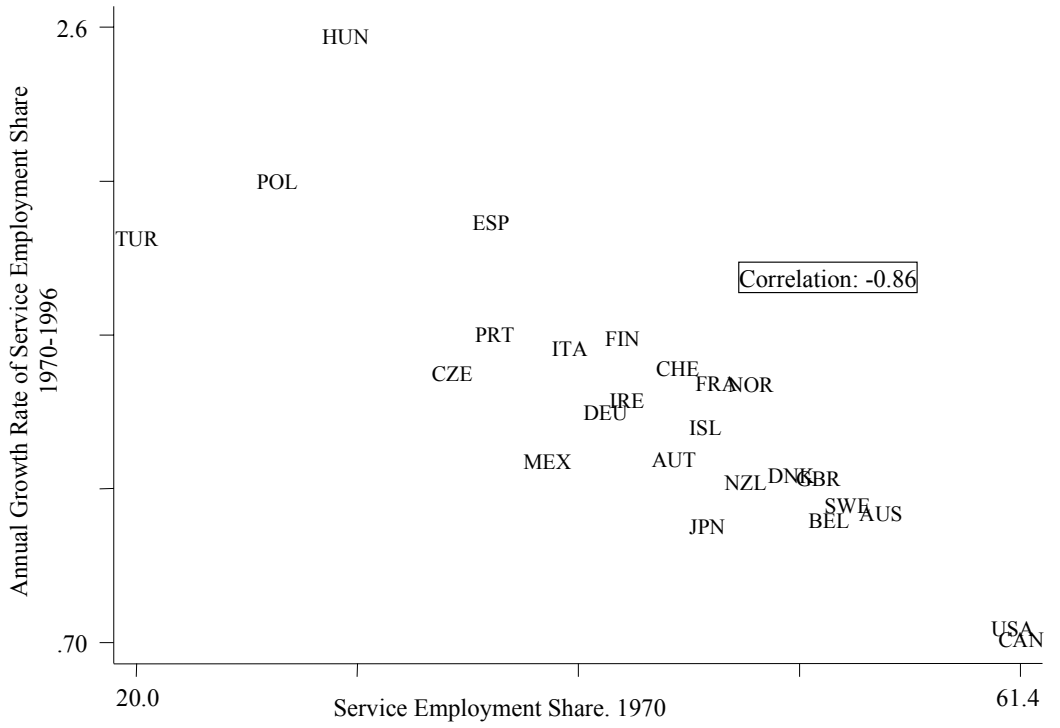

Figure 3: Convergence in the Service Employment Share. OECD Countries 


\section{European Central Bank working paper series}

For a complete list of Working Papers published by the ECB, please visit the ECB's website (http://www.ecb.int).

202 "Aggregate loans to the euro area private sector" by A. Calza, M. Manrique and J. Sousa, January 2003.

203 "Myopic loss aversion, disappointment aversion and the equity premium puzzle" by D. Fielding and L. Stracca, January 2003.

204 "Asymmetric dynamics in the correlations of global equity and bond returns" by L. Cappiello, R.F. Engle and K. Sheppard, January 2003.

205 "Real exchange rate in an inter-temporal n-country-model with incomplete markets" by B. Mercereau, January 2003.

206 "Empirical estimates of reaction functions for the euro area" by D. Gerdesmeier and B. Roffia, January 2003.

207 “A comprehensive model on the euro overnight rate” by F. R. Würtz, January 2003.

208 "Do demographic changes affect risk premiums? Evidence from international data" by A. Ang and A. Maddaloni, January 2003.

209 "A framework for collateral risk control determination" by D. Cossin, Z. Huang, D. Aunon-Nerin and F. González, January 2003.

210 "Anticipated Ramsey reforms and the uniform taxation principle: the role of international financial markets” by S. Schmitt-Grohé and M. Uribe, January 2003.

2II “Self-control and savings" by P. Michel and J.P. Vidal, January 2003.

212 "Modelling the implied probability of stock market movements" by E. Glatzer and M. Scheicher, January 2003.

213 “Aggregation and euro area Phillips curves” by S. Fabiani and J. Morgan, February 2003.

2I4 “On the selection of forecasting models" by A. Inoue and L. Kilian, February 2003.

215 "Budget institutions and fiscal performance in Central and Eastern European countries" by H. Gleich, February 2003.

216 "The admission of accession countries to an enlarged monetary union: a tentative assessment” by M. Ca'Zorzi and R. A. De Santis, February 2003.

217 "The role of product market regulations in the process of structural change" by J. Messina, March 2003. 
218 "The zero-interest-rate bound and the role of the exchange rate for monetary policy in Japan" by G. Coenen and V. Wieland, March 2003.

219 "Extra-euro area manufacturing import prices and exchange rate pass-through" by B. Anderton, March 2003.

220 "The allocation of competencies in an international union: a positive analysis" by M. Ruta, April 2003.

221 "Estimating risk premia in money market rates" by A. Durré, S. Evjen and R. Pilegaard, April 2003.

222 "Inflation dynamics and subjective expectations in the United States" by K. Adam and M. Padula, April 2003.

223 "Optimal monetary policy with imperfect common knowledge" by K. Adam, April 2003.

224 "The rise of the yen vis-à-vis the ("synthetic") euro: is it supported by economic fundamentals?" by C. Osbat, R. Rüffer and B. Schnatz, April 2003.

225 "Productivity and the ("synthetic") euro-dollar exchange rate" by C. Osbat, F. Vijselaar and B. Schnatz, April 2003.

226 "The central banker as a risk manager: quantifying and forecasting inflation risks" by L. Kilian and S. Manganelli, April 2003.

227 "Monetary policy in a low pass-through environment" by T. Monacelli, April 2003.

228 "Monetary policy shocks - a nonfundamental look at the data" by M. Klaeffing, May 2003.

229 “How does the ECB target inflation?" by P. Surico, May 2003.

230 "The euro area financial system: structure, integration and policy initiatives" by P. Hartmann, A. Maddaloni and S. Manganelli, May 2003.

23I "Price stability and monetary policy effectiveness when nominal interest rates are bounded at zero" by G. Coenen, A. Orphanides and V. Wieland, May 2003.

232 "Describing the Fed's conduct with Taylor rules: is interest rate smoothing important?" by E. Castelnuovo, May 2003.

233 "The natural real rate of interest in the euro area" by N. Giammarioli and N. Valla, May 2003.

234 "Unemployment, hysteresis and transition" by M. León-Ledesma and P. McAdam, May 2003.

235 "Volatility of interest rates in the euro area: evidence from high frequency data" by N. Cassola and C. Morana, June 2003. 
236 "Swiss monetary targeting 1974-1996: the role of internal policy analysis" by G. Rich, June 2003.

237 "Growth expectations, capital flows and international risk sharing" by O. Castrén, M. Miller and R. Stiegert, June 2003.

238 "The impact of monetary union on trade prices" by R. Anderton, R. E. Baldwin and D. Taglioni, June 2003.

239 "Temporary shocks and unavoidable transitions to a high-unemployment regime" by W. J. Denhaan, June 2003.

240 "Monetary policy transmission in the euro area: any changes after EMU?" by I. Angeloni and M. Ehrmann, July 2003.

24I Maintaining price stability under free-floating: a fearless way out of the corner?" by C. Detken and V. Gaspar, July 2003.

242 "Public sector efficiency: an international comparison" by A. Afonso, L. Schuknecht and V. Tanzi, July 2003.

243 “Pass-through of external shocks to euro area inflation” by E. Hahn, July 2003.

244 "How does the ECB allot liquidity in its weekly main refinancing operations? A look at the empirical evidence" by S. Ejerskov, C. Martin Moss and L. Stracca, July 2003.

245 "Money and payments: a modern perspective" by C. Holthausen and C. Monnet, July 2003.

246 "Public finances and long-term growth in Europe - evidence from a panel data analysis" by D. R. de Ávila Torrijos and R. Strauch, July 2003.

247 "Forecasting euro area inflation: does aggregating forecasts by HICP component improve forecast accuracy?" by K. Hubrich, August 2003.

248 "Exchange rates and fundamentals" by C. Engel and K. D. West, August 2003.

249 "Trade advantages and specialisation dynamics in acceding countries" by A. Zaghini, August 2003.

250 "Persistence, the transmission mechanism and robust monetary policy" by I. Angeloni, G. Coenen and F. Smets, August 2003.

25I "Consumption, habit persistence, imperfect information and the lifetime budget constraint" by A. Willman, August 2003.

252 "Interpolation and backdating with a large information set" by E. Angelini, J. Henry and M. Marcellino, August 2003.

253 "Bond market inflation expectations and longer-term trends in broad monetary growth and inflation in industrial countries, 1880-200I” by W. G. Dewald, September 2003. 
254 "Forecasting real GDP: what role for narrow money?" by C. Brand, H.-E. Reimers and F. Seitz, September 2003.

255 "Is the demand for euro area M3 stable?" by A. Bruggeman, P. Donati and A. Warne, September 2003.

256 "Information acquisition and decision making in committees: a survey" by K. Gerling, H. P. Grüner, A. Kiel and E. Schulte, September 2003.

257 "Macroeconomic modelling of monetary policy" by M. Klaeffling, September 2003.

258 "Interest rate reaction functions and the Taylor rule in the euro area" by P. GerlachKristen, September 2003.

259 "Implicit tax co-ordination under repeated policy interactions" by M. Catenaro and J.-P. Vidal, September 2003.

260 "Aggregation-theoretic monetary aggregation over the euro area, when countries are heterogeneous" by W. A. Barnett, September 2003.

261 "Why has broad money demand been more stable in the euro area than in other economies? A literature review" by A. Calza and J. Sousa, September 2003.

262 "Indeterminacy of rational expectations equilibria in sequential financial markets" by P. Donati, September 2003.

263 "Measuring contagion with a Bayesian, time-varying coefficient model" by M. Ciccarelli and A. Rebucci, September 2003.

264 "A monthly monetary model with banking intermediation for the euro area" by A. Bruggeman and M. Donnay, September 2003.

265 "New Keynesian Phillips Curves: a reassessment using euro area data" by P. McAdam and A. Willman, September 2003.

266 "Finance and growth in the EU: new evidence from the liberalisation and harmonisation of the banking industry" by D. Romero de Ávila, September 2003.

267 "Comparing economic dynamics in the EU and CEE accession countries" by R. Süppel, September 2003.

268 "The output composition puzzle: a difference in the monetary transmission mechanism in the euro area and the US" by I. Angeloni, A. K. Kashyap, B. Mojon and D. Terlizzese, September 2003.

269 "Zero lower bound: is it a problem with the euro area?" by G. Coenen, September 2003.

270 "Downward nominal wage rigidity and the long-run Phillips curve: simulation-based evidence for the euro area" by G. Coenen, September 2003.

27I "Indeterminacy and search theory" by N. Giammarioli, September 2003. 
272 "Inflation targets and the liquidity trap" by M. Klaeffling and V. López Pérez, September 2003.

273 "Definition of price stability, range and point inflation targets: the anchoring of long-term inflation expectations” by E. Castelnuovo, S. Nicoletti-Altimari and D. RodriguezPalenzuela, September 2003.

274 "Interpreting implied risk neutral densities: the role of risk premia" by P. Hördahl and D. Vestin, September 2003.

275 "Identifying the monetary transmission mechanism using structural breaks" by A. Beyer and R. Farmer, September 2003.

276 "Short-term estimates of euro area real GDP by means of monthly data" by G. Rünstler, September 2003.

277 "On the indeterminacy of determinacy and indeterminacy" by A. Beyer and R. Farmer, September 2003.

278 "Relevant economic issues concerning the optimal rate of inflation" by D. R. Palenzuela, G. Camba-Méndez and J. Á. García, September 2003.

279 "Designing targeting rules for international monetary policy cooperation" by G. Benigno and P. Benigno, October 2003.

280 “Inflation, factor substitution and growth" by R. Klump, October 2003.

28I "Identifying fiscal shocks and policy regimes in OECD countries" by G. de Arcangelis and S. Lamartina, October 2003.

282 "Optimal dynamic risk sharing when enforcement is a decision variable" by T. V. Koeppl, October 2003.

283 "US, Japan and the euro area: comparing business-cycle features” by P. McAdam, November 2003.

284 "The credibility of the monetary policy 'free lunch"' by J. Yetman, November 2003.

285 "Government deficits, wealth effects and the price level in an optimizing model" by B. Annicchiarico, November 2003.

286 "Country and sector-specific spillover effects in the euro area, the United States and Japan" by B. Kaltenhaeuser, November 2003.

287 “Consumer inflation expectations in Poland” by T. Łyziak, November 2003.

288 "Implementing optimal control cointegrated I(I) structural VAR models" by F. V. Monti, November 2003.

289 "Monetary and fiscal interactions in open economies" by G. Lombardo and A. Sutherland, November 2003. 
290 "Inflation persistence and robust monetary policy design" by G. Coenen, November 2003.

29I “Measuring the time-inconsitency of US monetary policy” by P. Surico, November 2003.

292 "Bank mergers, competition and liquidity" by E. Carletti, P. Hartmann and G. Spagnolo, November 2003.

293 “Committees and special interests” by M. Felgenhauer and H. P. Grüner, November 2003.

294 "Does the yield spread predict recessions in the euro area?" by F. Moneta, December 2003.

295 "Optimal allotment policy in the eurosystem's main refinancing operations?" by C. Ewerhart, N. Cassola, S. Ejerskov and N. Valla, December 2003.

296 "Monetary policy analysis in a small open economy using bayesian cointegrated structural VARs?" by M. Villani and A. Warne, December 2003.

297 “Measurement of contagion in banks' equity prices” by R. Gropp and G. Moerman, December 2003.

298 "The lender of last resort: a 2 I st century approach" by X. Freixas, B. M. Parigi and J.-C. Rochet, December 2003.

299 "Import prices and pricing-to-market effects in the euro area” by T. Warmedinger, January 2004.

300 "Developing statistical indicators of the integration of the euro area banking system" by M. Manna, January 2004.

301 “Inflation and relative price asymmetry” by A. Rátfai, January 2004.

302 “Deposit insurance, moral hazard and market monitoring” by R. Gropp and J. Vesala, February 2004.

303 "Fiscal policy events and interest rate swap spreads: evidence from the EU" by A. Afonso and R. Strauch, February 2004.

304 "Equilibrium unemployment, job flows and inflation dynamics" by A. Trigari, February 2004.

305 “A structural common factor approach to core inflation estimation and forecasting" by C. Morana, February 2004.

306 "A markup model of inflation for the euro area" by C. Bowdler and E. S. Jansen, February 2004.

307 "Budgetary forecasts in Europe - the track record of stability and convergence programmes" by R. Strauch, M. Hallerberg and J. von Hagen, February 2004.

308 "International risk-sharing and the transmission of productivity shocks" by G. Corsetti, L. Dedola and S. Leduc, February 2004.

309 "Monetary policy shocks in the euro area and global liquidity spillovers" by J. Sousa and A. Zaghini, February 2004.

310 "International equity flows and returns: A quantitative equilibrium approach" by R. Albuquerque, G. H. Bauer and M. Schneider, February 2004.

311 "Current account dynamics in OECD and EU acceding countries - an intertemporal approach" by M. Bussière, M. Fratzscher and G. Müller, February 2004. 
312 "Similarities and convergence in G-7 cycles" by F. Canova, M. Ciccarelli and E. Ortega, February 2004.

313 "The high-yield segment of the corporate bond market: a diffusion modelling approach for the United States, the United Kingdom and the euro area" by G. de Bondt and D. Marqués, February 2004.

314 "Exchange rate risks and asset prices in a small open economy" by A. Derviz, March 2004.

315 "Option-implied asymmetries in bond market expectations around money policy actions of the ECB" by S. Vähämaa, March 2004.

316 "Cooperation in international banking supervision" by C. Holthausen and T. Rønde, March 2004.

317 "Fiscal policy and inflation volatility" by P. C. Rother, March 2004.

318 "Gross job flows and institutions in Europe" by R. Gómez-Salvador, J. Messina and G. Vallanti, March 2004.

319 "Risk sharing through financial markets with endogenous enforcement of trades" by T. V. Köppl, March 2004. 320 "Institutions and service employment: a panel study for OECD countries" by J. Messina, March 2004. 
